\title{
PENGARUH PENAMBAHAN LEVEL VITAMIN E-SELENIUM DALAM PAKAN TERHADAP FERTILITAS DAN DAYA TETAS TELUR HASIL PERSILANGAN AYAM SENTUL DENGAN AYAM RAS PETELUR
}

\author{
The Effect of Vitamin E - Selenium Addition Level in Feed Against Fertility \\ and Hatching Eggs of Sentul Chicken Crosses With Laying Hens \\ Nining Haryuni, Anna Lidyawati, Binti Khopsoh \\ Department of Animal Husbandry, University of Nahdlatul Ulama Blitar. \\ Jl. Masjid No.22 Blitar \\ Email: niningharyuni@gmail.com
}

\begin{abstract}
The purpose of this research was to obtain a dose of vitamin E-selenium addition in feed on the quality of hatched eggs resulting from crossing Sentul chicken with laying hens. This research used 200 hatching eggs produced from the 34-week-old Isa Brown strain of laying hens which were treated and inseminated using Sentul chicken males. The experimental method used in this research was a completely randomized design CRD) with 5 treatments and 5 replications with each replication consisting of 8 hatching eggs. The treatments feed in this research were as follows: $P 0=$ Basal Feed, P1 = Basal Feed + 21.75 ppm vitamin $E$ and 0.23 ppm selenium, $P 2=$ Basal Feed +43.5 ppm vitamin $E$ and 0.46 ppm selenium, P3 = Basal Feed +65.25 ppm vitamin E and 0.69 ppm selenium, P4 = Basal Feed +87 ppm vitamin $E$ and 0.92 ppm selenium. The results of this research were that the addition of vitamin $E$-selenium levels in feed had no significant effect $(P>0.05)$ on the weight of hatching eggs, fertility, embryo mortality and hatchability.
\end{abstract}

Keywords: Vitamin E-Selenium Level, Feed, Hatching Eggs, Sentul Chicken, Laying Hens

\section{PENDAHULUAN}

Ayam buras merupakan unggas lokal asli Indonesia yang dikembangkan dalam upaya memenuhi kebutuhan daging dan telur yang diharapkan dapat mendukung kemandirian penyediaan pangan nasional. Hal ini sesuai dengan peraturan pemerintah Nomor 68 Tahun 2002 tentang ketahanan pangan dengan menekankan kemandirian penyediaan pangan berbasis sumber daya lokal. Peningkatan jumlah penduduk yang diiringi dengan kesadaran akan pentingnya nilai gizi menyebabkan kebutuhan pangan khususnya asal hewani mengalami peningkatan. Menurut Iskandar (2012) peningkatan konsumsi ayam buras disebabkan karena cita rasa dari daging ayam buras lebih disukai oleh konsumen dari pada daging ayam ras.

Peningkatan konsumsi daging ayam buras harus diimbangi dengan ketersediaan daging ayam buras, akan tetapi pengembangan ayam buras secara nasional masih tergolong rendah karena pada umumnya masih dimanfaatkan sebagai tambahan pendapatan. Peningkatan populasi ayam buras terus dilakukan salah satunya dengan memperbanyak jumlah populasi ayam buras dengan cara meningkatkan jumlah DOC (Day Old Chick). Kendala yang dihadapi dalam peningkatan jumlah DOC ayam buras adalah kurangnya jumlah induk dan sistem pemeliharaan yang masih konvensional. Hasil survei yang dilakukan oleh Suyatno (2003) di daerah Batu, Jawa Timur didapatkan bahwa penanganan reproduksi ayam buras masih dilakukan dengan menerapkan kawin alami yang secara ekonomis kurang efisien sebab membutuhkan pejantan dalam jumlah yang banyak. Hal senada juga diungkapkan oleh Utami (2009) bahwa kendala yang dihadapi dalam usaha komersial ayam buras yang dipelihara secara intensif adalah kurangnya pengadaan ayam dara untuk menggantikan induk produktif. Penggantian induk produktif masih didapatkan dari ayam dara hasil tetas dengan indukan sistem umbaran. Menurut Sutiyono et al. (2006) teknologi inseminasi buatan merupakan 
salah satu cara yang dapat digunakan untuk meningkatkan produktivitas ayam buras.

Upaya lainnya yang dilakukan untuk meningkatkan produktivitas ayam buras adalah dengan melakukan persilangan. Persilangan yang banyak dilakukan dimasyarakat adalah persilangan ayam sentul dengan ayam ras petelur. Menurut Mugiyono et al. (2015), ayam sentul jantan mempunyai kualitas yang unggul jika dibandingkan dengan ayam buras jenis lainnya. Pejantan ayam sentul mempunyai tingkat pertumbuhan yang cukup cepat dan kualitas spermatozoa yang unggul. Dalam upaya meningkatkan fertilitas dan daya tetas telur tetas yang dihasilkan dari persilangan tersebut maka perlu dilakukan penambahan vitamin E Selenium pada pakan.

Vitamin E merupakan salah satu antioksidan alami yang paling penting dan merupakan antioksidan yang berfungsi untuk melindungi sel dan jaringan dari kerusakan yang disebabkan oleh radikal bebas lipoperoksidatif (Tamzil, 2014). Vitamin E juga dapat digunakan untuk meningkatkan produktivitas pada unggas seperti penelitian yang telah dilakukan oleh Fauziah et al. (2013) bahwa suplementasi vitamin E yang dikombinasi dengan penambahan asam laktat dapat meningkatkan kecernaan lemak dan bobot telur ayam kedu. Dampak kekurangan vitamin E menurut Widodo (2010) pada ternak diantaranya pada ternak jantan dapat menyebabkan terjadinya degenerasi epitel germinal sedangkan pada ayam dewasa ditemukan adanya penurunan daya tetas dan kematian embrio. Selenium adalah komponen enzim glutation peroksidase, yang menghancurkan radikal bebas dalam sitoplasma. Fungsi lain selenium adalah sebagai antioksidan untuk komponen/bahan pembentuk enzim dan daya tahan tubuh serta reproduksi ternak (Lubis et al., 2015). Selenium merupakan komponen fungsional berbagai selenoprotein tubuh yang berinteraksi dengan vitamin E (Akil et al., 2009). Penelitian ini dilakukan untuk mendapatkan dosis penggunaan vitamin E-selenium pada pakan dalam upaya untuk meningkatkan kualitas telur tetas.

\section{MATERI DAN METODE}

\section{Materi}

Penelitian ini merupakan penelitian tahap kedua, dimana pada penelitian tahap kedua ini telur tetas didapatkan dari penelitian tahap pertama. Penelitian tahap pertama adalah penelitian eksperimental yaitu penambahan level vitamin E - Selenium dalam pakan ayam petelur yang diinseminasi buatan dengan pejantan ayam sentul. Pakan perlakuan pada penelitian tahap pertama adalah sebagai berikut:

P0 : Pakan Basal

P1 : Pakan basal $+21,75$ ppm vitamin $\mathrm{E}$ dan 0,23 ppm selenium

P2 : Pakan basal + 43,5 ppm vitamin E dan 0,46 ppm selenium

P3 : Pakan basal $+65,25$ ppm vitamin $\mathrm{E}$ dan 0,69 ppm selenium

P4 : Pakan basal + 87 ppm vitamin E dan 0,92 ppm selenium

Penambahan vitamin $\mathrm{E}$ dan selenium dilakukan tanpa merubah formulasi dari pakan yang digunakan. Kandungan nutrisi pakan perlakuan dapat dilihat pada Tabel 1 .

Penelitian tahap kedua ini menggunakan 200 butir telur tetas yang ayam petelur periode layer strain Isa Brown umur 34 minggu yang diberikan pakan perlakuan dan diinseminasi dengan menggunakan pejantan ayam sentul.

Tabel 1. Analisis proksimat kandungan nutrisi pakan perlakuan (Proximate analysis of the nutrient content of the treated feed)

\begin{tabular}{lc}
\hline $\begin{array}{c}\text { Nutrisi } \\
\text { (Nutrition) }\end{array}$ & $\begin{array}{c}\text { Pakan campuran } \\
\text { (Mixed feed })\end{array}$ \\
\hline GE(Kkal/kg) & 3364 \\
BK $(\%)$ & 89,30 \\
PK $(\%)$ & 19,36 \\
LK $(\%)$ & 3,27 \\
SK $(\%)$ & 7,20
\end{tabular}

Sumber : Laboratorium Dinas Peternakan dan Perikanan Kabupaten Blitar

\section{Metode}

Metode yang digunakan dalam penelitian ini adalah metode eksperimental dengan menggunakan Rancangan Acak Lengkap (RAL) dengan 5 perlakuan dan 5 kali ulangan dengan masing-masing ulangan terdiri dari 8 butir telur tetas.

\section{Prosedur Penelitian}

Telur tetas didapatkan dari penelitian tahap pertama. Penelitian tahap pertama adalah penelitian secara biologis di lapang yang dilakukan selama 10 minggu. Penempatan ayam jantan dan betina dilakukan secara terpisah dengan menggunakan kandang batteray. Pakan perlakuan diberikan 2 kali sehari dengan imbangan $40 \%$ pada pagi hari dan $60 \%$ diberikan pada sore hari. Imbangan pemberian pakan ini didasarkan pada rentang waktu yang dibutuhkan 
antara pemberian pakan pertama dengan pemberian pakan berikutnya. Pemberian pakan dilakukan pada pagi hari jam 07.00 pagi dan pada sore hari jam 14.00.

Pada penelitian ini perkawinan dilakukan dengan menggunakan teknologi inseminasi buatan (IB). Inseminasi buatan dilakukan setiap 4 hari sekali dan dilakukan pada sore hari. Telur tetas yang digunakan untuk penetasan pada penelitian ini diambil pada minggu ke-9. Telur tetas diambil kemudian dikumpulkan untuk dibersihkan. Cara membersihkan telur tetas yaitu dengan menggunakan kain lap bersih, kemudian diberi kode sesuai dengan perlakuan dan dilanjutkan untuk penetasan.

Pada saat penelitian berjalan selama 2 minggu ayam mengalami sedikit gangguan karena titer antibodi yang turun. Adapun hasil analisa laboratorium dengan menggunakan HI Test Method, titer antibodi AI (Avian Influenza) dan ND (New Casttle Desease) ayam pada saat penelitian dapat dilihat pada Tabel 2.

Tabel 2. Analisis titer anti bodi Avian Influenza dan Newcastle Disease induk (The analysis of hen's Avian Influenza and Newcastle Disease antibody titers)

\begin{tabular}{ccc}
\hline \multirow{2}{*}{$\begin{array}{c}\text { Perlakuan } \\
\text { (Treatment) }\end{array}$} & \multicolumn{2}{c}{$\begin{array}{c}\text { Rata-Rata Titer } \\
\text { (Average of Titers) }\end{array}$} \\
\cline { 2 - 3 } & $\begin{array}{c}\text { AI } \\
\text { (Avian Influenza) }\end{array}$ & $\begin{array}{c}\text { ND } \\
\text { (Newcastle Disease) }\end{array}$ \\
\hline P0 & $\log 2^{5}$ & $\log 2^{5}$ \\
P1 & $\log 2^{4}$ & $\log 2^{6}$ \\
P2 & $\log 2^{6}$ & $\log 2^{5}$ \\
P3 & $\log 2^{4}$ & $\log 2^{7}$ \\
P4 & $\log 2^{4}$ & $\log 2^{7}$ \\
\hline
\end{tabular}

Sumber : Laboratorium PT. Akurat Diagnostik Indonesia

\section{Variabel Yang Diamati}

1. Berat Telur Tetas

Pegambilan data berat telur tetas dilakukan dengan cara menimbang telur tetas sebelum dimasukkan kedalam mesin tetas.

\section{Fertilitas}

Penghitungan fertilitas dengan cara menghitung jumlah telur yang fertil atau dapat berkembang dengan melakukan candling dibandingkan telur yang dieramkan.

Fertilitas

$$
=\frac{\sum \text { Telur }-\sum \text { Telur yang infertil }}{\sum \text { Telur }} \times 100 \%
$$

\section{Mortalitas Embrio}

Penghitungan mortalitas embrio dilakukan dengan menggunakan rumus sebagai berikut :

\section{Mortalitas}

$$
=\frac{\sum \mathrm{T} \text {. fertil }-\sum \mathrm{T} \text {. tdk menetas }}{\sum \text { Telur fertil }} \times 100 \%
$$

\section{Daya Tetas}

Daya tetas adalah hasil telur yang fertil sampai dapat menetas dan dihitung pada akhir penetasan. Besarnya Daya Tetas dapat dihitung sebagai berikut:

$$
\begin{aligned}
& \text { Daya Tetas } \\
& =\frac{\sum \text { Telur yang menetas }}{\sum \text { Telur yang fertil }} \times 100 \%
\end{aligned}
$$

\section{HASIL DAN PEMBAHASAN}

Pengaruh penambahan level vitamin ESelenium dalam pakan terhadap kualitas telur tetas dapat dilihat pada Tabel 3.

\section{Pengaruh Perlakuan Terhadap Bobot Telur Tetas}

Hasil analisis statistik menunjukkan bahwa pemberian level vitamin E-selenium dalam pakan memberikan pengaruh yang tidak nyata ( $P>0.05)$ terhadap bobot telur tetas. Adanya pengaruh yang tidak nyata tersebut disebabkan karena kandungan energi dan lemak semua pakan perlakuan sama. Menurut Colombo (2010) vitamin $\mathrm{E}$ adalah vitamin yang larut dalam lemak dan penting untuk kesehatan. Kandungan energi dan lemak berpengaruh besar terhadap penyerapan vitamin E-selenium. Menurut Dror dan Allen (2011) vitamin E akan diserap oleh tubuh dengan adanya lemak pada makanan. Vitamin E akan dilepaskan ke jaringan tubuh seperti otot, adiposa dan otak dengan adanya lippoprotein lipase (LPL). Hal ini sesuai dengan penelitian yang dilakukan oleh Fauziah et al.,(2013) yang menyatakan bahwa penambahan vitamin $\mathrm{E}$ dan dan bakteri asam laktat dalam pakan memberikan pengaruh yang tidak nyata terhadap berat telur. 
Tabel 3. Data rataan berat telur tetas, fertilitas, mortalitas embrio dan daya tetas (Data on average hatching egg weight, fertility, embryo mortality and hatchability)

\begin{tabular}{ccccc}
\hline \multirow{2}{*}{$\begin{array}{c}\text { Perlakuan } \\
\text { Treatment })\end{array}$} & \multicolumn{4}{c}{$\begin{array}{c}\text { Rataan parameter } \\
\text { (Pararameter averaging) }\end{array}$} \\
\cline { 2 - 5 } & $\begin{array}{c}\text { Berat telur }(\mathrm{g}) \\
(\text { Egg weight })\end{array}$ & $\begin{array}{c}\text { Fertilitas }(\%) \\
(\text { Fertility) }\end{array}$ & $\begin{array}{c}\text { Mortalitas embrio }(\%) \\
(\text { Embryo mortality) }\end{array}$ & $\begin{array}{c}\text { Daya tetas }(\%) \\
(\text { hatchability) }\end{array}$ \\
\hline P0 & $58.95^{\mathrm{a}}$ & $39.20^{\mathrm{a}}$ & $8.01^{\mathrm{a}}$ & $36.00^{\mathrm{a}}$ \\
P1 & $59.03^{\mathrm{a}}$ & $36.80^{\mathrm{a}}$ & $7.72^{\mathrm{a}}$ & $34.00^{\mathrm{a}}$ \\
P2 & $58.68^{\mathrm{a}}$ & $34.80^{\mathrm{a}}$ & $9.80^{\mathrm{a}}$ & $31.40^{\mathrm{a}}$ \\
P3 & $59.28^{\mathrm{a}}$ & $34.80^{\mathrm{a}}$ & $6.95^{\mathrm{a}}$ & $32.40^{\mathrm{a}}$ \\
P4 & $58.19^{\mathrm{a}}$ & $37.80^{\mathrm{a}}$ & $4.90^{\mathrm{a}}$ & $36.00^{\mathrm{a}}$
\end{tabular}

$\overline{\text { Keterangan : Superskrip yang sama pada kolom yang sama menunjukkan bahwa perlakuan memberikan }}$ pengaruh yang tidak nyata $(\mathrm{P}>0.05)$

Berat telur berdasarkan SNI (2008) digolongkan menjadi 3 kriteria yaitu telur kecil (berat $<50 \mathrm{~g}$ ), telur sedang (berat antara $50-60 \mathrm{~g}$ ) dan telur besar (berat $>60 \mathrm{~g}$ ). Salah satu kriteria yang digunakan untuk seleksi telur tetas adalah berat telur. Berat telur yang digunakan dalam penelitian ini tergolong dalam telur sedang dimana rata-rata berat telur sekitar 58,19 - 59,28g. Telur tetas yang digunakan dalam penelitian ini sudah memenuhi standar jika dilihat dari berat telur dan mempunyai berat yang seragam. Hal ini sesuai dengan Susanto dan Suliswanto (2013) yang menyatakan bahwa telur yang baik digunakan untuk penetasan adalah telur dengan ukuran sedang. Telur dengan kriteria terlalu ringan atau terlalu berat sulit untuk menetas. Telur yang terlalu ringan embrio sulit untuk berkembang karena komposisi nutrisi dalam telur kurang sedangkan telur yang terlalu berat poripori lebih besar sehingga penguapan menjadi lebih besar yang menyebabkan embrio akan mati sebelum menetas.

\section{Pengaruh Perlakuan Terhadap Fertilitas}

Fertilitas merupakan suatu kondisi yang menunjukkan kesuburan dan kemampuan induk untuk menghasilkan keturunan (Helendra et al., 2012). Hasil analisis statistik menunjukkan bahwa pemberian level vitamin E-selenium dalam pakan memberikan pengaruh yang tidak nyata $(\mathrm{P}>0.05)$ terhadap fertilitas. Hal ini disebabkan karena pada saat berjalannya penelitian induk mengalami sakit akibat titer antibodi ND (New Castle Desease) dan AI (Avian Influenza) rendah. Kandungan energi dan lemak pada perlakuan adalah sama hal ini berpengaruh pada penyerapan vitamin Eselenium yang tidak berbeda sehingga respon induk terhadap tingkat stress yang dipicu oleh kegiatan inseminasi buatan dan penyakit adalah sama. Menurut Tufarelli dan Laudadio (2016) stress oksidatif merupakan salah satu faktor utama yang berpengaruh pada parameter tingkat kesuburan pada unggas. Helendra et al., (2011) yang menyebutkan bahwa salah satu faktor penting yang mempengaruhi tingginya fertilitas adalah status kesehatan induk.

Selain faktor kesehatan induk faktor lain yang berpengaruh terhadap fertilitas adalah iklim, varietas ayam, sistem perkawinan, pakan, umur induk, penanganan dan penyimpanan telur tetas sebelum masuk mesin tetas (Rajab, 2013), imbangan jantan dan betina, cahaya dan abnormalitas spermatozoa (Badaruddin et al., 2017).

\section{Pengaruh Perlakuan Terhadap Mortalitas Embrio}

Mortalitas embrio adalah besarnya persentase yang menggambarkan besarnya telur fertil yang tidak dapat menetas (Bachari et al., 2006). Hasil analisis statistik menunjukkan bahwa pemberian level vitamin E-selenium dalam pakan memberikan pengaruh yang tidak nyata $(\mathrm{P}>0.05)$ terhadap mortalitas embrio. Hal ini disebabkan karena beberapa faktor yaitu pertama karena adanya virus ND dalam telur dan kedua karena kandungan energi dan lemak pada pakan perlakuan adalah sama sehingga tingkat penyerapan vitamin E-selenium juga sama. Hasil penelitian Wibowo et al., (2017) didapatkan bahwa isolat virus ND yang diinokulasikan pada telur tetas dapat menyebabkan terjadinya kematian embrio selama kurang lebih 28 jam. Menurut Sulistyaningrum et al., (2019) mortalitas embrio disebabkan karena ketidakmampuan organ embrio dalam menyerap albumin dan yolk (kuning telur).

\section{Pengaruh perlakuan terhadap Daya Tetas}

Daya tetas merupakan persentase yang menggambarkan jumlah telur fertil yang dapat menetas (Bachari et al., 2006). Daya tetas yang 
didapatkan pada penelitian ini jauh dibawah standar dimana pada penelitian ini daya tetas hanya berkisar antara $31.04-36 \%$. Menurut Susanto dan Suliswanto (2013) standar nilai daya tetas ayam kampung adalah $60 \%$.

Hasil analisis statistik menunjukkan bahwa pemberian level vitamin E-selenium dalam pakan memberikan pengaruh yang tidak nyata $(\mathrm{P}>0.05)$ terhadap daya tetas. Hal ini kemungkinan disebabkan karena terdapat virus ND dan AI pada telur yang ditetaskan pada penelitian ini. Hal ini sesuai dengan Napirah dan Has (2017) yang menyatakan bahwa adanya infeksi mikroorganisme dalam telur dapat menurunkan daya tetas telur.

Adanya virus ND dan AI dalam telur disebabkan karena induk betina mempunyai titer anti bodi ND dan AI yang rendah pada saat penelitian biologis. Hal ini sesuai dengan Elfidasari dan Puspitasari (2013) yang menyatakan bahwa virus AI yang ada pada induk bisa ditularkan ke DOC melalui telur. Hal senada juga dikemukakan oleh Indriani dan Dharmayanti (2006) bahwa identifikasi titer antibodi terhadap virus AI dapat dilakukan dengan menggunakan kuning telur.

\section{SIMPULAN}

Simpulan dari penelitian ini adalah penambahan vitamin E-selenium dalam pakan memberikan pengaruh yang tidak nyata terhadap bobot telur tetas, fertilitas, mortalitas embrio dan daya tetas.

\section{UCAPAN TERIMA KASIH}

Ucapan terima kasih kami sampaikan kepada Direktorat Riset dan Pengabdian Masyarakat Kemenristek DIKTI yang telah memberikan dana dalam penelitian

\section{DAFTAR PUSTAKA}

Akil, S., W.G. Piliang., C.H. Wijaya., D.B. Utomo dan I.K.G. Wiryawan. 2009. Pengkayaan Selenium Organik, Inorganik dan Vitamin E dalam Pecan Puyuh terhadap Performa serta Potensi Telur Puyuh sebagai Sumber Antioksidan. JITV 14(1):1-10.

Bachari. I., I. Sembiring dan D.S. Tarigan. 2006. Pengaruh Frekuensi Pemutaran Telur terhadap Daya Tetasdan Bobot Badan DOC Ayam Kampung. J. Agribisnis Peternakan 2(3): 101-105.
Colombo, M.L. 2010. An Update on Vitamin E, Tocopherol and Tocotrienol Perspectives. Molecules J. 15: 2103-2113.

Dror, D.K and L.H. Allen. 2011. Vitamin E Defciency In Developing Countries. Food and Nutrition Bulletin 32 (2) : 124-143.

Elfidasari, D dan R. L. Puspitasari. 2013. Analisa Cross-Infection Virus AI Subtipe H5N1 Berdasarkan Imunoserologi pada Burung Airdi Cagar Alam Pulau Dua. J. Al-Azhar Indonesia Seri Sains Dan Teknologi 2(2): 120-128.

Fauziah, A., I. Mangisah dan W. Murningsih. 2013. Pengaruh Penambahan Vitamin E Dan Bakteri AsamLaktat Terhadap Kecernaan Lemak Dan Bobot Telur Ayam Kedu Hitam Dipelihara Secara In Situ. Anim. Agri. J. 2(1): 319-328.

Helendra, Imanidar dan R. Sumarmin. 2011. Fertilitas Dan Daya Tetas Telur Ayam Kampung (Gallus Domestica) Dari Kota Padang. J. EKSAKTA 1: 29-37.

Indriani, R dan N.L.P.I. Dharmayanti. 2006. Deteksi Antibodi Avian Influenza dalam Kuning Telur Ayam Pasca Vaksinasi (AI) Subtipe H5N1. Media Kedokteran Hewan 22(2): 84-88.

Iskandar, S. 2012. Optimalisasi Protein dan Energi Ransum Untuk Meningkatkan Produksi Daging Ayam Lokal. Pengembangan Inovasi Pertanian 5(2):96107.

Lubis, F.L.N., R. Afianti dan E. Sahara. 2015. Pengaruh Suplementasi Selenium Organik (Se) dan Vitamin E terhadap Performa Itik Pegagan. J. Peternakan Sriwijaya 4(1): 2834.

Napirah, A dan H. Has. 2017. Pengaruh Lama Penyimpanan Terhadap Fertilitas Dan Daya Tetas Telur Ayam Kampung Persilangan. Prosiding Seminar Nasional Riset Kuantitatif Terapan. Kendari. Pp.167-170.

Rajab. 2013. Hubungan Bobot Telur Dengan Fertilitas, Daya Tetas, Dan Bobot Anak Ayam Kampung. J. Agrinimal 3(2):56-60.

Standar Nasional Indonesia (SNI). 2008. Telur Ayam Konsumsi. Badan Standarisasi Nasional ICS.67.120.20.

Sulistyaningrum, A.D., Mudawamah dan Sunaryo. 2019. Evaluasi Performans Penetasan Berdasarkan Umur Induk di Hatchery PT. Intertama Trikencana Bersinar Deli Serdang Sumatra Utara. J. Rekasatwa Peternakan 1(1): 59-63. 
Susanto, E. dan Suliswanto. 2013. Pengaruh Berat Telur Terhadap Daya Tetas Telur Ayam Kampung. J. Ternak 4(2): 27-30.

Sutiyono, S. Riyadi dan S. Kismiati. 2006. Fertilitas Dan Daya Tetas Telur Dari Ayam Petelur Hasil Inseminasi Buatan Menggunakan Semen Ayam KampungYang Diencerkan Dengan Bahan Berbeda. J. Indonesian Anim. Agr. 31(1): 36-40.

Suyatno. 2003. Peningkatan Produksi Bibit Ayam LurikMelalui Penerapan Inseminasi Buatan. J. Dedikasi 1(1): 104-111.

Tamzil, M.H. 2014. Stres Panas pada Unggas: Metabolisme, Akibat dan Upaya Penanggulangannya. Wartazoa 24(2): 5766.

Tufarelli, V and V. Laudadio. 2016. Antioxidant Activity Of Vitamin E And Its Role In Avian Reproduction. J. of Experimental Biology and Agr. Sci. 4(3) : 266-272.

Utami, I.A.P. 2009. Daya Tahan Spermatozoa Ayam Buras (Peranakan Sentul) Pada Tiga Macam Pengencer. J. Ganec Swara 3(3): 39-42.

Wibowo, S.E., M.H. Wibowo dan B. Sutrisno. 2017. Penentuan Patogenesitas Molekuler Virus Newcastle Disease yang Diisolasi dari Ayam Komersial Tahun 2013-2016. J. Acta Veterinaria Indonesiana 5(2): 105119.

Widodo, W. 2010. Nutrisi Dan Pakan Unggas Kontekstual. Buku Ajar Fakultas Peternakan Universitas Muhammadiyah Malang.

http://wahyuwidodo.staff.umm.ac.id/files/ 2010/01/NUTRISI_DAN_PAKAN_UNG GAS_KONTEKSTUAL.pdf 